\title{
Effect of Planting Depth and Mulching Materials on Yield and Yield Attributes of Potato in Dadeldhura, Nepal
}

\author{
Binod Joshi $^{1,}$ *, Roshan Dhakal ${ }^{1}$, Santosh Bharati ${ }^{1}$, Shiva Chandra Dhakal ${ }^{2}$, Khem Raj Joshi ${ }^{3}$ \\ ${ }^{1}$ Faculty of Agriculture, Agriculture and Forestry University, Rampur, Chitwan, Nepal \\ ${ }^{2}$ Department of Economy, Agriculture and Forestry University, Chitwan, Nepal \\ ${ }^{3}$ Prime Minister Agriculture Modernization Project, Dadeldhura, Nepal
}

Email address:

biratbinod@gmail.com (B. Joshi)

${ }^{*}$ Corresponding author

\section{To cite this article:}

Binod Joshi, Roshan Dhakal, Santosh Bharati, Shiva Chandra Dhakal, Khem Raj Joshi. Effect of Planting Depth and Mulching Materials on Yield and Yield Attributes of Potato in Dadeldhura, Nepal. International Journal of Applied Agricultural Sciences.

Vol. 9, No. 3, 2019, pp. 45-53. doi: 10.11648/j.aff.20200903.12

Received: August 26, 2019; Accepted: September 18, 2019; Published: May 28, 2020

\begin{abstract}
Potato, a staple crop for hill and mountainous region has significant contribution in maintaining food and nutrition security. It alone shares around $2.17 \%$ of Gross Domestic Product. With phenomenal climate change, pest and disease are increased, hills are and mountains are getting dried leading to moisture deficit which in turn are decreasing the yield of potato. So, with this existing trouble this study has focused to discover innovation in major two agronomic practices: planting depth and mulching. But, the farmer of Nepal often uses haphazard planting depth and mulching which contribute to the low yield. Thus, in order to study, its effect on planting depth and mulching, a research was conducted in the Dadeldhura district of Nepal in 2019. The research was carried out in factorial $2 \times 3$ Randomized Complete Block Design which consist of mulch and unmulched condition as $1^{\text {st }}$ factor and three different planting depth of $(10 \mathrm{~cm}, 15 \mathrm{~cm}$ and $20 \mathrm{~cm})$ as $2^{\text {nd }}$ factor. So altogether there are six treatments with four replications. Data were collected on growth, tuber yield and quality parameter and analyzed using R-studio software. Regarding $1^{\text {st }}$ factor, mulched treatment was found significantly superior than un-mulched treatment in case of all yield attributes like plant height, stem number, canopy and leaves number. Total tuber yield was found $3.626 \mathrm{~kg} / \mathrm{m}^{2}$ in mulch treatment which was highly significant $(\mathrm{P}<0.01)$. In case of $2^{\text {nd }}$ factor, tuber planted at a depth of $15 \mathrm{~cm}$ produced maximum number of aerial stem per plant $5.2(\mathrm{P}<0.001)$ number of large size tuber per plant $9.025(\mathrm{P}<0.01)$ and tuber yield $3.82 \mathrm{~kg} / \mathrm{m}^{2}(\mathrm{P}<0.01)$ as compared to other planting depth of $10 \mathrm{~cm}$ and $20 \mathrm{~cm}$. There was no any significant difference in case of interaction between the two factors. Therefore, it can be concluded from the result that with the use of mulching and planting depth of $15 \mathrm{~cm}$ all yield attributes and yield of potato was found to be superior under the climatic condition of Dadeldhura, Nepal.
\end{abstract}

Keywords: Potato, Depth, Mulch, Tuber, Yield, Growth, Quality, RCBD

\section{Introduction}

Nepal is the country where agriculture is considered is leading source of livelihood as $66 \%$ are directly engaged in farming. Agriculture contributes around $26.24 \%$ to Nepal GDP, out of which potato share about $2.17 \%$ to Gross Domestic Product (GDP) and $6.57 \%$ to Agriculture Gross Domestic Product [1]. The total production of potato in 2017 was 388,191,000 metric tons being China becoming the highest producer of potato in the world [2]. Potato is cultivated from $100 \mathrm{~m}$ altitude in south to $4000 \mathrm{~m}$ altitude in north. According to the recent statistics potato rank first in productivity (13.1 t/ha), second in quantity of production (25, 86,287 tons) and fifth in area coverage $(1,97,037 \mathrm{ha})$ after rice, wheat, maize and finger millet. Potato is one of the major food crops of Nepal which is cultivated in 1, 85,879 ha and it is second important cash crop in Nepal after oilseed (2, 07,978 ha). The different varieties of potato found to be cultivated in Nepal are Cardinal, Kufri sinduri, Khumal rato, Desiree and so on [3]. Potato crop is third most consumed crop globally after rice and wheat [4]. 
The time and energy of sprout to emerge is affected by planting depth. The shallow planting depth limit the rapid emergence due to less moisture content [5]. In case of deep planting, as potato tuber has to come across long distance of ground to emerge so, it took more time to emerge [6]. With the increase in shallow planting depth, emergence rate is accelerated [7]. Mulching helps in the earlier germination of tuber by regulating temperature and moisture [8]. According to Pavek and Thornton (2009), the development of below ground morphology, tuber expansion and yield are determined by the planting depth. Mulching with plastic film on the potato improved tuber yields and water use efficiency, with increased economic benefits [9]. Mulching maintain optimum moisture condition, reduce evaporation, regulate temperature, increases soil microbial biomass, reduces fertilizers leaching as well as soil salinity and increase nutrient availability whereas indirectly favors growth of plant by reducing pathogen and weed number, increasing photosynthesis and root biomass. Highest tuber number is observed in mulching than un-mulching as mulching help to regulate the temperature, maintain proper environmental condition [10]. With the increasing planting depth the number of tuber per plant increases as there is availability of moisture with increasing depth [11]. With the use of mulching the number of large size tuber per plant increases which may be due to the positive effect of mulching on tuber as it helps to regulate temperature and maintain the moisture content $[12,13]$. In our nation there is limited research this field. Therefore, this study was conducted to know the effect of different planting depth and mulching on yield and yield attributes of potato in Dadeldhura district.

\section{Materials and Methods}

\subsection{Experimental Site}

The research experiment entitled "Effect of different planting depth and mulching on yield and yield attributes of potato in Dadeldhura district, Nepal "was carried out at Dadeldhura district Nepal during 2018-2019. The study site is located at $28^{\circ} 59^{\prime \prime} \mathrm{N}$ to $29^{\circ} 26^{\prime \prime} \mathrm{N}$ latitude and $80^{\circ} 12^{\prime \prime}$ to $80^{\circ} 47^{\prime \prime}$ longitude in the humid sub-tropical zone with elevation of 17,45 masl.

\subsection{Climatic Condition at Experimental Site}

The data regarding the maximum and minimum temperature, rainfall, relative humidity and bright sunshine during the experiment period of 3.5 month from March to June 2019 was recorded from the Department of Hydrology and Meteorology, Dadeldhura. The average relative humidity was found $54.22 \%$ during the experiment. Similarly, the average maximum temperature was $23.53^{\circ} \mathrm{C}$ which ranged from $13.70-33.10^{\circ} \mathrm{C}$ whereas the average minimum temperature was $12.09^{\circ} \mathrm{C}$ which ranged from $1.30-17.70^{\circ} \mathrm{C}$. The average precipitation of $1.09 \mathrm{~mm}$ with $100.6 \mathrm{~mm}$ rainfall was observed in the experimental field. The average bright sunshine of 8.07 hundredths of an hour with total 742.0 hundredths of an hour was observed in the experimental area.

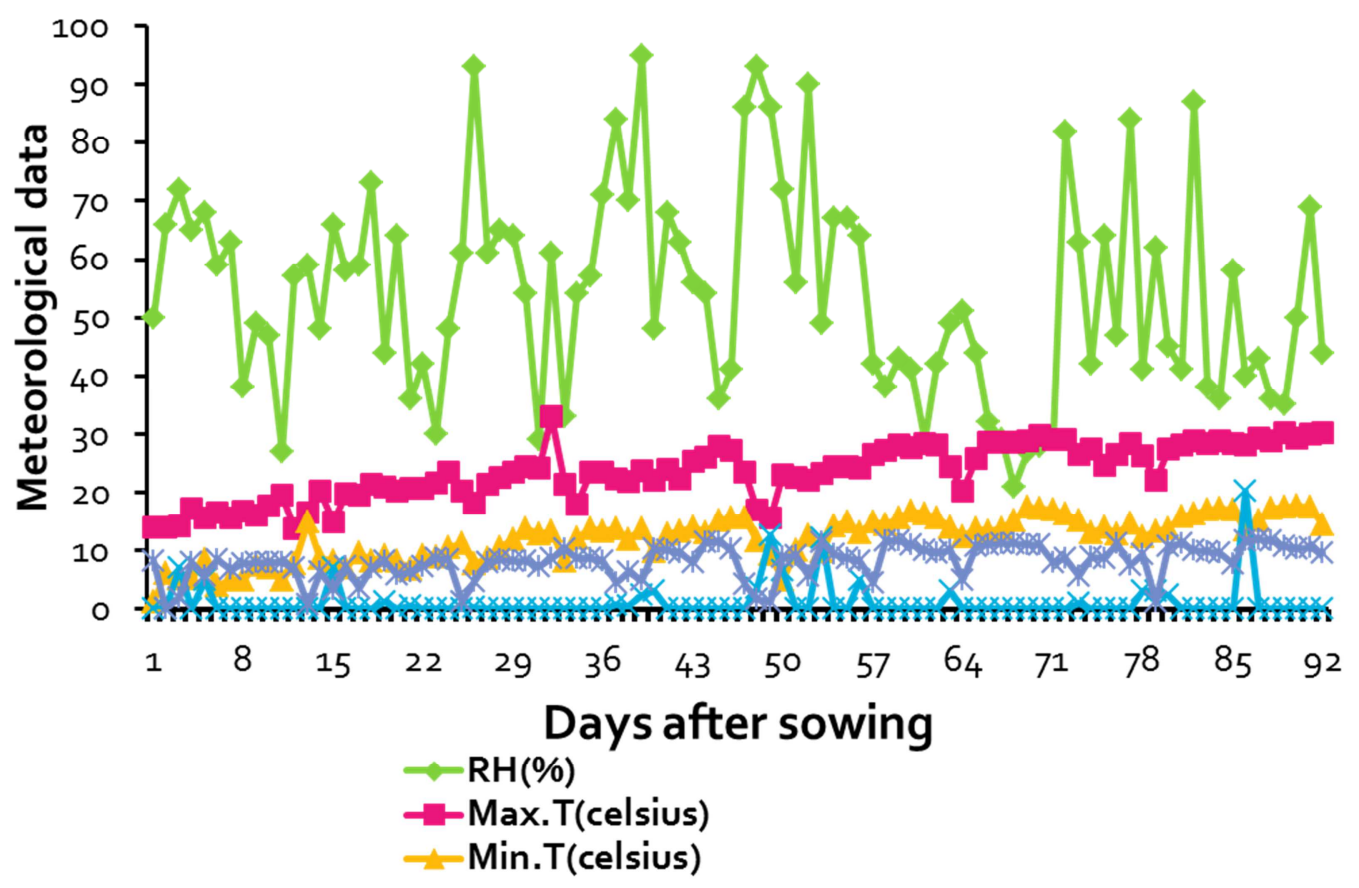

Figure 1. Meteorological parameters (Relative humidity, Maximum Temperature, Minimum Temperature, Rainfall, Bright Sunshine) during the crop duration at experimental site.

\subsection{Experimental Design, Layout and Methodology}

The field experiment was carried out on factorial RCBD with two factor, four replication and six treatment in total land area of $117.04 \mathrm{~m}^{2}(15.2 \mathrm{~m} * 7.7 \mathrm{~m})$ at Tadibata (Bhatkada) farm of Dadeldhura, district. Each replication consists of six treatment plot each of area $3.6 \mathrm{~m}^{*} 1 \mathrm{~m}$ that were placed through randomization. The Desiree cultivar of potato was 
taken for the experimental study of our research project. The Desiree variety of potato was sown on March 1, 2019. Crop geometry was maintained of $60 * 20 \mathrm{~cm}$. Plot size was $3.6 * 1$ $\mathrm{m}^{2}$ where 6 rows with 5 plants/ row was planted

The soil was made harrowed until completely free of weed roots. About three ploughing, along with the harrowing, was done before the soil would reach a suitable condition: soft, well-drained and well-aerated. Ridge and furrow will be made on the field and black-plastic mulch (silver color on underside) will be used to cover the ridges. For Desiree variety of potato the recommended dose of fertilizers is used i.e, FYM: $1500 \mathrm{~kg} /$ ropani, Urea: 7kg/ropani, DAP: 11 $\mathrm{kg} /$ ropani and MOP: $5 \mathrm{~kg}$ /ropani. All the fertilizers according to above doses were incorporated into the field before sowing. Due to mulches on the field, all the doses of nitrogen were given as the basal dose at the time of sowing.

The description on factor and treatment that were used were given below:

Table 1. Details of different factor and their symbol used in the experiment.

\begin{tabular}{lll}
\hline S. N. & $1^{\text {ST }}$ FACTOR & Abbreviation \\
& Mulch & M \\
& Un-mulch & UM \\
S. N. & $2^{\text {nd }}$ factor & Abbreviation \\
& Depth $(10 \mathrm{~cm})$ & 10 \\
& Depth $(15 \mathrm{~cm})$ & 15 \\
& Depth $(20 \mathrm{~cm})$ & 20 \\
\hline
\end{tabular}

Table 2. Details of the different treatment and their abbreviation used in the experiment.

\begin{tabular}{lll}
\hline S. N. & Treatment & Abbreviation \\
\hline 1. & Mulch with $10 \mathrm{~cm}$ depth & $\mathrm{M}+10$ \\
2. & Mulch with $15 \mathrm{~cm}$ depth & $\mathrm{M}+15$ \\
3. & Mulch with $20 \mathrm{~cm}$ depth & $\mathrm{M}+20$ \\
4. & Un-mulch with $10 \mathrm{~cm}$ depth & $\mathrm{UM}+10$ \\
5. & Un-mulch with $15 \mathrm{~cm}$ depth & $\mathrm{UM}+15$ \\
6. & Un-mulch with $20 \mathrm{~cm}$ depth & $\mathrm{UM}+20$ \\
\hline
\end{tabular}

\subsection{Data Collection and Analysis}

The five plants were tagged randomly from each plot for the collection of data. The data regarding to plant height, canopy, leaves number and aerial stem per plant were taken at 45, 60 and 75 days after planting as well as other data of tuber number, yield, marketable tuber and unmarketable tuber were also taken.

The data collected were entered in MS-Excel and then analyzed by using $\mathrm{R}$ studio software. The means were compared by using Duncan's Multiple Range test (DMRT) at $5 \%$ level of significance.

\section{Result and Discussion}

\subsection{Days After Germination}

$90 \%$ germination was significantly affected by first factor (mulching), whereas there is no significant difference in case of second factor as well as in interaction (Table 3). The germination percentage was found significant in case of first factor; in which mulching favors the earlier 90 percentage DAP as compared to unmulching. Similarly, in case of second factor it was found insignificant but earlier 90 percentage germination was observed in planting depth of $15 \mathrm{~cm}$ (36days) followed by $10 \mathrm{~cm}(36.875)$ and $20 \mathrm{~cm}(37.375)$ respectively. There was no significant difference in case of interaction between two factors but earlier 90 percentage germination was observed in $\mathrm{M}+15$ (33.75) and delayed germination was observed in UM+20 (38.75).

Both the mulching and planting depth effect on the germination percentage of tuber. The earlier and increase in germination (\%) at $15 \mathrm{~cm}$ depth is favored by the presence of ideal temperature and soil moisture which is similar to the experimental finding [14] .

Table 3. Effect of different treatment on $90 \%$ germination, days after planting at different factor at Dadeldhura, Nepal, 2019.

\begin{tabular}{ll}
\hline Treatment & GDAP \\
\hline $1^{\text {st }}$ factor & $35^{\mathrm{b}}$ \\
$\mathrm{M}$ & $38.5^{\mathrm{a}}$ \\
$\mathrm{U}$ & 0.704 \\
Sem $( \pm)$ & $* *$ \\
F-test & 2.12 \\
LSD & \\
$2^{\text {nd }}$ factor & 36.875 \\
10 & 36 \\
15 & 37.375 \\
20 & 0.8624 \\
Sem $( \pm)$ & $\mathrm{NS}$ \\
F-test & 2.6 \\
LSD & \\
INTERACTION & 35.25 \\
M +10 & 33.75 \\
M +15 & 36 \\
M +20 & 38.5 \\
U+10 & 38.25 \\
U+15 & 38.75 \\
U+20 & NS \\
F-test & 1.2197 \\
SEM $( \pm)$ & 3.68 \\
LSD & 6.64 \\
CV & 36.8 \\
Grand Mean & \\
\hline
\end{tabular}

Note: $($ GDAP $=$ Days after planting, treatment means with the same letter do not differ significantly at $\mathrm{p}=0.05$ by DMRT. $\mathrm{CV}=$ Coefficient of variation. $\mathrm{LSD}=$ least significant difference, $\mathrm{SEM}=$ Standard error of mean)

\subsection{Plant Height and Canopy}

Plant height is one of the yield attributing parameter. There were comparable difference between the different treatment which is presented in the Table 4 . Regarding $1^{\text {st }}$ factor, plant height was found significantly higher in mulching (23.45, 33.233 and 34.3916) as compared to un-mulching (17, 25.516 and 27.819) at 45, 60 and 75 DAP respectively. The insignificant result on plant height was found in between second treatment at 45 and 60DAP. At 75 DAP, plant height was found significantly higher in $15 \mathrm{~cm}$ depth (33.55) which was at par with $10 \mathrm{~cm}$ depth (31.975) and lowest in $20 \mathrm{~cm}$ depth. In case of interaction between first and second factor there is no any significant difference among the different 
treatment combination but highest plant height was recorded in $\mathrm{M}+15(26.9,34.25$ and 36.35$)$ at 45,60 and 75 DAP $)$ respectively as compared to other treatment combination.

Canopy length is another important parameter, in which tuber yield depends to certain extent. In case of first factor, the canopy length was found insignificant at 45DAP in mulching whereas at 60 and 75DAP there was significant difference in mulching as compared with un-mulching. Regarding, second factor at 45DAP, canopy length was found insignificant in planting depth but at 60 and 75DAP, canopy length was found significant in planting depth having maximum canopy length in $15 \mathrm{~cm}$ with $(51.72$ and 53.9$)$ followed by $10 \mathrm{~cm}$ depth (46.175 and 51.17$)$ and minimum in $20 \mathrm{~cm}$ depth (40.025 and 46.515) respectively. In case of interaction between first and second factor, there is no any significant difference among the different treatment combination but the maximum canopy length was found in $(\mathrm{M}+15)$ mulching with $15 \mathrm{~cm}$ depth $(38.275,54.775$ and $54.55)$ at 45,60 and 75 DAP respectively as compared to other treatment combination.

Table 4. Plant height and canopy of potato at different days after planting as influenced by different factors at Dadeldhura, Nepal during 2019.

\begin{tabular}{|c|c|c|c|c|c|c|}
\hline \multirow{2}{*}{ Treatment } & \multicolumn{4}{|c|}{ Plant height (cm) } & \multirow{2}{*}{$\begin{array}{l}\text { Canopy }(\mathrm{cm}) \\
\text { 60DAP }\end{array}$} & \multirow{2}{*}{ 75DAP } \\
\hline & 45 DAP & 60DAP & 75DAP & 45 DAP & & \\
\hline \multicolumn{7}{|l|}{$1^{\text {st }}$ Factor } \\
\hline M & $23.45^{\mathrm{a}}$ & $33.233^{\mathrm{a}}$ & $34.39167^{\mathrm{a}}$ & 35.0583 & $49.367^{\mathrm{a}}$ & $51.80083^{\mathrm{a}}$ \\
\hline UM & $17^{\mathrm{b}}$ & $25.516^{\mathrm{b}}$ & $27.819^{b}$ & 33.125 & $42.583^{b}$ & $49.2625^{\mathrm{b}}$ \\
\hline F-test & $* * *$ & $* * *$ & $* *$ & NS & $* * *$ & $*$ \\
\hline $\operatorname{Sem}( \pm)$ & 1.03008 & 1.20 & 1.24043 & 1.6931 & 1.0979 & 0.8205 \\
\hline \multicolumn{6}{|l|}{$2^{\text {nd }}$ Factor } & 2.47 \\
\hline $10 \mathrm{~cm}$ & 20.00 & $30.425^{\mathrm{a}}$ & $31.975^{\mathrm{ab}}$ & 33.5375 & $46.175^{\mathrm{b}}$ & $51.17^{\mathrm{a}}$ \\
\hline $15 \mathrm{~cm}$ & 22.100 & $30.825^{\mathrm{a}}$ & $33.550^{\mathrm{a}}$ & 36.2375 & $51.725^{\mathrm{a}}$ & $53.90^{\mathrm{a}}$ \\
\hline $20 \mathrm{~cm}$ & 18.575 & $26.875^{\mathrm{a}}$ & $27.9^{\mathrm{b}}$ & 32.5 & $40.025^{\mathrm{c}}$ & $46.51^{b}$ \\
\hline F-test & NS & NS & $*$ & NS & $* * *$ & $* * *$ \\
\hline $\operatorname{Sem}( \pm)$ & 1.2615 & 1.4794 & 1.5192 & 2.0736 & 1.3446 & 1.0049 \\
\hline LSD & 3.8 & 4.46 & 4.58 & 6.25 & 4.05 & 3.03 \\
\hline \multicolumn{7}{|l|}{ Interaction } \\
\hline $\mathrm{M}+10$ & 22.55 & 34.6 & 35.375 & 35.95 & 50.075 & 51.96 \\
\hline $\mathrm{M}+15$ & 26.90 & 34.25 & 36.350 & 38.275 & 54.775 & 54.55 \\
\hline $\mathrm{M}+20$ & 20.9 & 30.85 & 31.450 & 35.125 & 43.25 & 48.8875 \\
\hline $\mathrm{U}+10$ & 17.45 & 26.6 & 28.575 & 31.125 & 42.275 & 50.375 \\
\hline $\mathrm{U}+15$ & 17.30 & 27.05 & 30.750 & 34.2 & 48.675 & 53.2625 \\
\hline $\mathrm{U}+20$ & 16.25 & 22.90 & 24.350 & 29.975 & 36.8 & 44.15 \\
\hline F-test & NS & NS & NS & NS & NS & NS \\
\hline $\operatorname{Sem}( \pm)$ & 1.78416 & 2.09224 & 2.1484 & 2.9325 & 1.9016 & 1.42117 \\
\hline LSD & 5.38 & 6.31 & 6.48 & 8.84 & 5.73 & 4.28 \\
\hline $\mathrm{CV}$ & 17.6 & 14.2 & 13.8 & 17.2 & 8.27 & 5.62 \\
\hline Grand mean & 20.2 & 29.4 & 31.1 & 34.1 & 46 & 50.5 \\
\hline
\end{tabular}

Note: $(\mathrm{DAP}=$ Days after planting, treatment means with the same letter do not differ significantly at $\mathrm{p}=0.05$ by DMRT. $\mathrm{CV}=\mathrm{Coefficient}$ of variation. $\mathrm{LSD}=$ least significant difference, $\mathrm{SEM}=$ Standard error of mean)

\subsection{Leaves Number}

Significant variation was observed in number of leaves per plant with different planting depth and mulching as shown in Table 5. The leaves number were found significantly higher in mulching (34.25 and 36.667) as compared to un-mulching (27.34167, and 33.015) at 45 and 75 DAP respectively, but at 60DAP leaf number was found non-significant in mulching however highest leaf number is reported in mulching (37.083) than un-mulching (32.550). In case of second factor, there was significant difference at different days after planting. The leaves number were found significantly higher in $15 \mathrm{~cm}$ depth of planting $(36.825,43.8$ and 39.75), followed by $10 \mathrm{~cm}$ depth of planting $(29.875,33.4625$ and 33.975) and minimum number was recorded in $20 \mathrm{~cm}$ depth of planting $(25.6875,27.5250$ and 30.8). In case of interaction between first and second factor, there was no any significant difference among the different treatment combination but highest leaves number was recorded in $\mathrm{M}+15$ (40.8, 46.1. and 40.4) at 45, 60and 75 DAP respectively. At $15 \mathrm{~cm}$ depth elements required for plant growth are available at optimum amount as $15 \mathrm{~cm}$ depth is not too close to surface where soil dry up quickly as well as not too deep where there is problem of proper aeration so more number of leaves are recorded at $15 \mathrm{~cm}$ depth.

Similar result with increased number of leaves at $15 \mathrm{~cm}$ depth was observed in potato as compared to $10 \mathrm{~cm}$ and $20 \mathrm{~cm}$ depth [15]. At upper surface of soil there is more water stress which ultimately suppresses cell expansion and cell growth due to low turgor pressure.

Table 5. leaves number of potato at different days after planting as influenced by different factors at Dadeldhura, Nepal during 2019.

\begin{tabular}{llll}
\hline \multirow{2}{*}{ Treatment } & \multicolumn{2}{l}{ Leaves number } & \multirow{2}{*}{ 75DAP } \\
\cline { 2 - 3 } & 45DAP & 60DAP & \\
\hline $1^{\text {st }}$ factor & & & $36.667^{\mathrm{a}}$ \\
$\mathrm{M}$ & 34.25 & 37.3083 & $33.01^{\mathrm{b}}$ \\
$\mathrm{U}$ & 27.34167 & 32.550 & $*$ \\
F-test & $* *$ & $\mathrm{NS}$ & \\
\hline
\end{tabular}




\begin{tabular}{llll}
\hline \multirow{2}{*}{ Treatment } & \multicolumn{2}{l}{ Leaves number } & \multirow{2}{*}{ 75DAP } \\
\cline { 2 - 3 } & 45DAP & 60DAP & \\
\hline Sem $( \pm)$ & 1.543 & 1.6658 & 1.0135 \\
LSD & 4.65 & 5.02 & 3.06 \\
$2^{\text {nd }}$ factor & & & \\
$10 \mathrm{~cm}$ & $29.875^{\mathrm{b}}$ & $33.4625^{\mathrm{b}}$ & $33.975^{\mathrm{b}}$ \\
$15 \mathrm{~cm}$ & $36.825^{\mathrm{a}}$ & $43.8^{\mathrm{a}}$ & $39.75^{\mathrm{a}}$ \\
$20 \mathrm{~cm}$ & $25.6875^{\mathrm{b}}$ & $27.5250^{\mathrm{b}}$ & $30.8^{\mathrm{b}}$ \\
F-test & $* *$ & $* * *$ & $* * *$ \\
Sem $( \pm)$ & 1.890 & 2.0402 & 1.2413 \\
LSD & 5.7 & 6.15 & 3.75 \\
Interaction & & & \\
M+10 & 35.25 & 36.825 & 36.55 \\
$\mathrm{M}+15$ & 40.8 & 46.1 & 40.4 \\
M+20 & 26.7 & 29.0 & 33.05 \\
$\mathrm{U}+10$ & 24.5 & 30.1 & 31.4 \\
$\mathrm{U}+15$ & 32.85 & 41.5 & 39.1 \\
$\mathrm{U}+20$ & 24.675 & 26.05 & 28.55 \\
F-test & $\mathrm{NS}$ & $\mathrm{NS}$ & $\mathrm{NS}$ \\
Sem $( \pm)$ & 2.674 & 2.885 & 1.755 \\
LSD & 8.06 & 8.7 & 5.3 \\
CV & 17.4 & 16.5 & 10.1 \\
GM & 30.8 & 34.9 & 34.8 \\
\hline
\end{tabular}

Note: $(\mathrm{DAP}=$ Days after planting, treatment means with the same letter do not differ significantly at $\mathrm{p}=0.05$ by DMRT. $\mathrm{CV}=$ Coefficient of variation. $\mathrm{LSD}=$ least significant difference, $\mathrm{SEM}=$ Standard error of mean)

\subsection{Aerial Stem Per Plant}

Aerial stem is another major parameter influencing the yield of potato tuber. On this parameter, there was significant effect of planning depth and mulching which is presented in the Table 6 . However, all the interaction were found non-significant. Mulching produces significantly higher (4.8333) aerial stem /plant as compared to unmulching (4.125). Similarly, in case of second factor planting depth of $15 \mathrm{~cm}$ with 5.20 aerial stem per plant was found significantly highest $(\mathrm{p}<0.001)$ than other treatment which was at par with $10 \mathrm{~cm}$ depth (4.8125 aerial stem/plant) and lowest number was observed in $20 \mathrm{~cm}$ depth $(3.125$ aerial stem/plant). There was no any significant interaction between the two factors but the highest number of aerial stem per plant was reported in $\mathrm{M}+15$ (5.5 aerial stem/plant) and lowest in $\mathrm{UM}+20$ (3.15 aerial stem per plant). Maximum number of aerial stem per plant at $15 \mathrm{~cm}$ depth was produced due to the favorable environmental condition such as temperature, moisture and soil air, which is in accordance with the experimental finding [16]. Mulching helps to preserve the soil moisture content and regulate temperature and without mulch there is more moisture and drought stress that ultimately reduce the number of stem as identified in the finding [17].

Table 6. Aerial stem number per plant of potato at different days after planting as influenced by different factors at Dadeldhura, Nepal during 2019.

\begin{tabular}{ll}
\hline Treatment & Aerial Stem Per Plant \\
\hline $1^{\text {st }}$ factor & \\
$\mathrm{M}$ & $4.8333^{\mathrm{a}}$ \\
$\mathrm{U}$ & $4.125^{\mathrm{b}}$ \\
F-test & $*$ \\
\hline
\end{tabular}

\begin{tabular}{ll}
\hline Treatment & Aerial Stem Per Plant \\
\hline Sem $( \pm)$ & 0.17884 \\
LSD & 0.539 \\
$2^{\text {nd }}$ Factor & \\
$10 \mathrm{~cm}$ & $4.8125^{\mathrm{a}}$ \\
$15 \mathrm{~cm}$ & $5.20^{\mathrm{a}}$ \\
$20 \mathrm{~cm}$ & $3.425^{\mathrm{b}}$ \\
F-test & $* * *$ \\
Sem $( \pm)$ & 0.21903 \\
LSD & 0.66 \\
Interaction & \\
M +10 & 5.3 \\
M +15 & 5.5 \\
M +20 & 3.7 \\
U+10 & 4.325 \\
U+15 & 4.9 \\
U +20 & 3.15 \\
F-test & NS \\
Sem $( \pm)$ & 0.30976 \\
LSD & 0.933 \\
CV & 13.8 \\
\hline
\end{tabular}

Note: (Means with the same letter do not differ significantly at $\mathrm{p}=0.05$ by DMRT. $C V=$ Coefficient of variation. $L S D=$ least significant difference, $\mathrm{SEM}=$ Standard error of mean. $\mathrm{DAP}=$ Days after planting).

\subsection{Shoot Dry Weight, Tuber Dry Weight and Harvest Index}

In case of first factor, shoot dry weight was found insignificant but highest shoot dry weight were found in mulching (0.034) as compared to un-mulching as shown in Table 7. In case of second factor, shoot dry weight was found significantly higher in $15 \mathrm{~cm}$ depth $(0.0377)$ which was statistically at par with $10 \mathrm{~cm}$ depth and lowest in $20 \mathrm{~cm}$ depth (0.02544). There was found significant difference in case of interaction between the different treatment combinations having significantly higher value in $\mathrm{M}+15$ whereas lowest value is observed in $\mathrm{UM}+20$.

The tuber dry weight was found significantly higher in mulching (0.10444) as compared to un-mulching (0.08132) in case of first factor. The insignificant difference in tuber dry weight was observed in case of second factor but the highest tuber dry weight was observed in $15 \mathrm{~cm}(0.11010)$ as compared to other treatment. In case of interaction between first and second factor, there was no any significant difference among the different treatment combination but highest tuber dry weight was observed in $\mathrm{M}+15$ (0.11940) as compared to other different treatment combination. The increased in dry shoot weight and tuber dry weight in mulch and planting depth of $15 \mathrm{~cm}$ might be due to the optimum moisture condition favorable for growth as well as due to maximum accumulation of dry matter through photosynthesis.

In case of first factor, harvest index was found insignificant but highest harvest index was found in mulching (0.7513579) as compared to un-mulching as shown in table 8. There was found insignificant difference in case of second factor too, but have highest value in $15 \mathrm{~cm}(0.749200)$ and lowest in $20 \mathrm{~cm}$ depth $(0.7372340)$. There was found 
insignificant difference in case of interaction between the different treatment combinations.

Table 7. Shoot dry weight, Tuber dry weight and Harvest index at different days after planting as influenced by different factors at Dadeldhura, Nepal during 2019.

\begin{tabular}{|c|c|c|c|}
\hline Treatment & $\begin{array}{l}\text { Shoot dry } \\
\text { weight }\end{array}$ & $\begin{array}{l}\text { Tuber dry weight } \\
\text { (kg/plant) }\end{array}$ & $\begin{array}{l}\text { harvest index } \\
\text { (HI) }\end{array}$ \\
\hline \multicolumn{4}{|l|}{$1^{\text {st }}$ factor } \\
\hline M & 0.03460667 & 0.10444 & 0.7513579 \\
\hline UM & 0.030740 & 0.08132 & 0.721078 \\
\hline F-test & NS & $*$ & NS \\
\hline $\operatorname{Sem}( \pm)$ & 0.0018078 & 0.00603 & 0.01603 \\
\hline LSD & 0.00545 & 0.0182 & 0.0483 \\
\hline \multicolumn{4}{|l|}{$2^{\text {nd }}$ factor } \\
\hline $10 \mathrm{~cm}$ & $0.0348725^{\mathrm{a}}$ & 0.09192 & 0.7221309 \\
\hline $15 \mathrm{~cm}$ & $0.0377^{\mathrm{a}}$ & 0.11010 & 0.749200 \\
\hline $20 \mathrm{~cm}$ & $0.0254475^{b}$ & 0.07662 & 0.7372340 \\
\hline F-test & $* *$ & NS & NS \\
\hline $\operatorname{Sem}( \pm)$ & 0.002214 & 0.00739 & 0.0964 \\
\hline LSD & 0.00667 & 0.0223 & 0.0592 \\
\hline \multicolumn{4}{|l|}{ Interaction } \\
\hline $\mathrm{M}+10$ & $0.033205^{\mathrm{bc}}$ & 0.09864 & 0.7452268 \\
\hline$M+15$ & $0.045675^{\mathrm{a}}$ & 0.11940 & 0.7246915 \\
\hline$M+20$ & $0.024940^{\mathrm{c}}$ & 0.09528 & 0.781553 \\
\hline $\mathrm{UM}+10$ & $0.036540^{\mathrm{ab}}$ & 0.08520 & 0.6990351 \\
\hline $\mathrm{UM}+15$ & $0.029725^{\mathrm{bc}}$ & 0.10080 & 0.7738886 \\
\hline $\mathrm{UM}+20$ & $0.025955^{\mathrm{c}}$ & 0.05796 & 0.6903128 \\
\hline F-test & $*$ & NS & NS \\
\hline $\operatorname{Sem}( \pm)$ & 0.00313 & 0.01046 & 0.02777 \\
\hline LSD & 0.00944 & 0.03 & 0.0837 \\
\hline $\mathrm{CV}$ & 19.2 & 22.5 & 7.54 \\
\hline Grand mean & 0.0327 & 0.0929 & 0.736 \\
\hline
\end{tabular}

(Treatment means with the same letter do not differ significantly at $\mathrm{p}=0.05$ by DMRT. $\mathrm{CV}=$ Coefficient of variation. $\mathrm{LSD}=$ least significant difference, $\mathrm{SEM}=$ Standard error of mean)

\subsection{Number of Tuber $m^{-2}$ and Tuber Yield $m^{-2}$}

In case of first factor, there was no any significant difference but, highest tuber number was recorded in mulching (90.55193) as compared to un-mulching (84.024425) as shown in the table 8. In case of second factor, there was significant difference and statistically highest $(<0.0$ 1) in $15 \mathrm{~cm}$ depth with 108.53733 tuber number per meter square whereas lowest tuber number is observed in $20 \mathrm{~cm}$ depth (75.20533) which is statistically at par with $10 \mathrm{~cm}$ depth (78.121885). In case of interaction between the two factor, there is no any significant difference the treatment combination but the highest tuber number was found in $\mathrm{M}+15$ (Mulching with $15 \mathrm{~cm}$ depth) and lowest in $\mathrm{UM}+20$ (un-mulched with $20 \mathrm{~cm}$ depth). Planting at $15 \mathrm{~cm}$ depth produces higher number of aerial stem per plant and maximum number of leaves that enhanced the photosynthetic area which ultimately help to increase the number of tuber.

The mean value of data given in Table 8 indicated that planting depth and mulch had significantly affected the total tuber yield $\left(\mathrm{kg} / \mathrm{m}^{2}\right)$. There were significant difference between the different combinations used in the experiment.
Mulching treatment was found significantly higher $(\mathrm{p}<0.01)$ than the un-mulching treatment with $3.626244 \mathrm{~kg}$ average tuber yield per meter square. Similarly, in case of second factor, planting depth with $15 \mathrm{~cm}$ was found significantly highest $(\mathrm{p}<0.01)$ with $3.822764 \mathrm{~kg} / \mathrm{m}^{2}$, followed by $\left(3.191539 \mathrm{~kg} / \mathrm{m}^{2}\right)$ at $10 \mathrm{~cm}$ depth whereas minimum $\left(2.660310 \mathrm{~kg} / \mathrm{m}^{2}\right)$ yield was obtained at $10 \mathrm{~cm}$ planting depth. There was no any significant interaction between the two but the tuber yield was found highest in $\mathrm{M}+15$ and lowest in $\mathrm{UM}+20$. There was significantly maximum number of aerial stem and leaves per plant at $15 \mathrm{~cm}$ depth of planting that enhanced the photosynthetic area of plant and spontaneously resulted in maximum tuber yield of potato. At $10 \mathrm{~cm}$ depth there was generally high soil temperature and as a result stolonization was gradually compromised and there was no underground tuber development. At $10 \mathrm{~cm}$ depth there was high soil temperature and as a result tuberization process was delayed at above $20^{\circ} \mathrm{C}$ (Rykaczewska, 2013).

Table 8. Tuber number and yield per meter square at different days after planting as influenced by different factors at Dadeldhura, Nepal during 2019.

\begin{tabular}{|c|c|c|}
\hline Treatment & Tuber no (number $/ \mathrm{m}^{2}$ ) & Tuber yield $\left(\mathrm{kg} / \mathrm{m}^{2}\right)$ \\
\hline \multicolumn{3}{|l|}{$1^{\text {st }}$ factor } \\
\hline M & 90.55193 & $3.62644^{\mathrm{a}}$ \\
\hline UM & 84.02442 & $2.823498^{\mathrm{b}}$ \\
\hline F-test & NS & $* *$ \\
\hline $\operatorname{Sem}( \pm)$ & 4.664 & 0.16635 \\
\hline LSD & 14.1 & 0.501 \\
\hline \multicolumn{3}{|l|}{$2^{\mathrm{ND}}$ factor } \\
\hline $10 \mathrm{~cm}$ & $78.12188^{b}$ & $3.191539^{b}$ \\
\hline $15 \mathrm{~cm}$ & $108.53733^{\mathrm{a}}$ & $3.822764^{\mathrm{a}}$ \\
\hline $20 \mathrm{~cm}$ & $75.20533^{b}$ & $2.660310^{\mathrm{b}}$ \\
\hline F-test & $* *$ & $* *$ \\
\hline $\operatorname{Sem}( \pm)$ & 5.712 & 0.2037 \\
\hline LSD & 17.2 & 0.614 \\
\hline \multicolumn{3}{|l|}{ Interaction } \\
\hline $\mathrm{M}+10$ & 72.49710 & 3.424863 \\
\hline$M+15$ & 117.07865 & 4.145668 \\
\hline $\mathrm{M}+20$ & 82.08005 & 3.308201 \\
\hline $\mathrm{UM}+10$ & 83.74665 & 2.958215 \\
\hline $\mathrm{UM}+15$ & 99.99600 & 3.499860 \\
\hline $\mathrm{UM}+20$ & 68.33060 & 2.012420 \\
\hline F-test & NS & NS \\
\hline $\operatorname{Sem}( \pm)$ & 8.078 & 0.28814 \\
\hline LSD & 24.4 & 0.869 \\
\hline Grand mean & 87.3 & 3.22 \\
\hline CV & 18.5 & 17.9 \\
\hline
\end{tabular}

(Treatment means with the same letter do not differ significantly at $\mathrm{p}=0.05$ by DMRT. $\mathrm{CV}=$ Coefficient of variation. $\mathrm{LSD}=$ least significant difference, $\mathrm{SEM}=$ Standard error of mean)

\subsection{Grading of Tuber on the Basis of Diameter}

Unmarketable tuber yield was highly significant $(\mathrm{p}<0.01)$ at mulching and planting depth factor whereas, the interaction effect between mulching and planting depth was found insignificant $(p>0.05)$ as shown in Table 9. The unmarketable tuber number were statistically highest in un- 
mulching (2.15) than mulching (1.533) whereas in case of second factor, unmarketable tuber number were statistically highest in $20 \mathrm{~cm}$ depth which is statistically at par with $10 \mathrm{~cm}$ depth and lowest number were recorded in $15 \mathrm{~cm}$ depth. There is no any significant difference in case of interaction between the different treatment combination but highest unmarketable number were recorded in $(\mathrm{UM}+20$ and $\mathrm{U}+10)$ and lowest number is recorded in Mulch with $15 \mathrm{~cm}$ depth $(\mathrm{M}+15)$.

In case of MRS (Marketable tuber for seed), there was found insignificant difference in first factor but the highest number is reported in mulching (6.033) as compared to unmulching (5.63) as shown in Table 9. Regarding to second factor (planting depth), there was found significant difference $(\mathrm{P}<0.05)$ having maximum seed tuber number in $15 \mathrm{~cm}$ depth (7.15) and lowest tube number is observed in $20 \mathrm{~cm}$ depth (4.5) and in between them in the $10 \mathrm{~cm}$ depth. However, there is no any significant difference in case of interaction between first and second factor treatment combination but highest marketable tuber for seed is observed in $\mathrm{M}+15$ (7.25) and lowest in $\mathrm{UM}+20$ (4.85).

In case of MRST (Marketable potato for seed as well as for tuber) first factor was found significantly highest $(\mathrm{P}<0.05)$ in mulching (2.533) as compared to un-mulching (1.625) as shown in Table 9. Regarding second factor, there was found insignificant difference but having maximum tuber number in $15 \mathrm{~cm}$ depth (2.325), followed by $10 \mathrm{~cm}$ depth (2.225) and lowest in $20 \mathrm{~cm}$ depth (2.125). However, in case of interaction between first and second factor there was no any significant difference among different treatment combination but highest tuber number is observed in $\mathrm{M}+15$ (2.75) and lowest in $\mathrm{UM}+20$ (1.9) as compared to other treatment combination.

Table 9. Grading of tuber on the basis of diameter as influenced by different factors at Dadeldhura, Nepal during 2019.

\begin{tabular}{|c|c|c|c|c|}
\hline Treatment & $\begin{array}{l}\text { UMS } \\
(<1 \mathrm{CM})\end{array}$ & $\begin{array}{l}\text { MRS } \\
(1-2.5 \mathrm{~cm})\end{array}$ & $\begin{array}{l}\text { MRST } \\
(2.6-3.5 \mathrm{~cm})\end{array}$ & $\begin{array}{l}\text { MT } \\
(>3.5 \mathrm{~cm})\end{array}$ \\
\hline \multicolumn{5}{|l|}{$1^{\mathrm{ST}}$ factor } \\
\hline M & $1.5333^{b}$ & 6.033 & $2.533^{\mathrm{a}}$ & $2.09167^{\mathrm{a}}$ \\
\hline $\mathrm{U}$ & $2.15^{\mathrm{a}}$ & 5.65 & $1.91667^{\mathrm{b}}$ & $1.625^{\mathrm{b}}$ \\
\hline F-test & $* *$ & NS & * & * \\
\hline $\operatorname{Sem}( \pm)$ & 0.21168 & 0.46031 & 0.15972 & 0.12561 \\
\hline LSD & 0.367 & 1.39 & 0.481 & 0.379 \\
\hline \multicolumn{5}{|l|}{$2^{\text {nd }}$ Factor } \\
\hline $10 \mathrm{~cm}$ & $1.9^{\mathrm{a}}$ & $5.955^{\mathrm{ab}}$ & 2.225 & $1.875^{\mathrm{ab}}$ \\
\hline $15 \mathrm{~cm}$ & $1.425^{\mathrm{b}}$ & $7.100^{\mathrm{a}}$ & 2.325 & $2.15^{\mathrm{a}}$ \\
\hline $20 \mathrm{~cm}$ & $2.20^{\mathrm{a}}$ & $4.5^{\mathrm{b}}$ & 2.125 & $1.550^{\mathrm{b}}$ \\
\hline F-test & $* *$ & $*$ & NS & $*$ \\
\hline LSD & 0.449 & 1.7 & 0.59 & 0.464 \\
\hline $\operatorname{Sem}( \pm)$ & 0.14861 & 0.5640 & 0.19561 & 0.15384 \\
\hline \multicolumn{5}{|l|}{ Interaction } \\
\hline $\mathrm{M}+10$ & 1.45 & 5.55 & 2.35 & 2.45 \\
\hline$M+15$ & 1.10 & 7.25 & 2.75 & 1.950 \\
\hline$M+20$ & 2.05 & 4.15 & 2.50 & 1.875 \\
\hline $\mathrm{U}+10$ & 2.35 & 6.30 & 2.10 & 1.8 \\
\hline
\end{tabular}

\begin{tabular}{lllll}
\hline Treatment & $\begin{array}{l}\text { UMS } \\
(<\mathbf{1 C M})\end{array}$ & $\begin{array}{l}\text { MRS } \\
(\mathbf{1 - 2 . 5 c m})\end{array}$ & $\begin{array}{l}\text { MRST } \\
\mathbf{( 2 . 6 - 3 . 5 c m )}\end{array}$ & $\begin{array}{l}\text { MT } \\
(>\mathbf{3 . 5 c m})\end{array}$ \\
\hline $\mathrm{U}+15$ & 1.75 & 6.95 & 1.9 & 1.85 \\
$\mathrm{U}+20$ & 2.35 & 4.85 & 1.75 & 1.225 \\
F-test & $\mathrm{NS}$ & $\mathrm{NS}$ & $\mathrm{NS}$ & $\mathrm{NS}$ \\
Sem $( \pm)$ & 0.21016 & 0.79762 & 0.27664 & 0.21756 \\
LSD & 0.635 & 2.41 & 0.834 & 0.656 \\
CV & 22.9 & 27.3 & 24.9 & 23.4 \\
Grand mean & 1.84 & 5.84 & 2.23 & 1.86 \\
\hline
\end{tabular}

(Means with the same letter do not differ significantly at $\mathrm{p}=0.05$ by DMRT. $\mathrm{CV}=$ Coefficient of variation. $\mathrm{LSD}=$ least significant difference, $\mathrm{SEM}=$ Standard error of mean. $\mathrm{DAP}=$ Days after planting) and (UMS indicates "Unmarketable seed", MRS indicates "Marketable tuber used for seed purpose', MRST indicate "Marketable potato for tuber as well as for seed purpose" and MT indicate "Marketable tuber used for consumption only").

\subsection{Grading of Tuber on the Basis of Weight}

Data related to number of large size tuber per plant is presented in the table 10 . In case of first factor, mulching treatment was found significantly highest $(p<0.05)$ with 7.9833 number of tuber per plant as compared to unmulching with 6.45 tuber per plant. There was found significant difference in case of second factor as well with highest number of large size tuber per plant (9.025) and lowest number is reported in $20 \mathrm{~cm}$ depth (5.455) which is statistically at par with $10 \mathrm{~cm}$ depth (7.125). However, there was no any significant interaction between the two factors but the highest number was observed in $M+15$ (9.7) and lowest in $\mathrm{UM}+20$ (4.20).

There was found significant difference in case of first factor regarding medium size tuber per plant as shown in table 10. Mulching treatment was found significantly higher $(\mathrm{P}<0.01)$ with 3.7333 medium size tuber than un-mulching with 2.60 tuber per plant. Likewise, in case of second factor planting depth of $15 \mathrm{~cm}$ with 3.75 medium size tuber per plant was found statistically highest $(\mathrm{P}<0.05)$ which was at par with $10 \mathrm{~cm}$ depth (3.35 medium size tuber/plant) and lowest number of medium size tuber per plant is noted in $20 \mathrm{~cm}$ depth (2.4). Similarly, in case of interaction also there was found significant difference among the different treatment combination. Medium size tuber per plant was found statistically highest in $\mathrm{M}+15$ (5.1), whereas lowest number were recorded in $\mathrm{UM}+20$ (2.2) which is statistically at par with $\mathrm{M}+10$ (3.5), $\mathrm{UM}+10$ (3.2), $\mathrm{M}+20$ (2.6), $\mathrm{UM}+15$ (2.4) respectively. The data presented in the Table 10 show the significant difference among the mulching factor and planting depth factor whereas the interaction between the two factors was found insignificant. Un-Mulching treatment was found statistically higher $(\mathrm{P}<0.05)$ than mulching. Likewise, in case of second factor planting depth of $20 \mathrm{~cm}$ with 0.625 small size tuber was found significantly highest $(\mathrm{P}<0.05)$ which was at par with $10 \mathrm{~cm}$ depth $(0.5)$, whereas lowest number were recorded in $15 \mathrm{~cm}$ depth $(0.425)$ which is also statistically at par with $10 \mathrm{~cm}$ depth 
Table 10. Grading of tuber on the basis of weight as influenced by different factors at Dadeldhura, Nepal during 2019.

\begin{tabular}{|c|c|c|c|}
\hline Treatment & LST $(>50 \mathrm{gm}) /$ plant & $\begin{array}{l}\text { MST } \\
(25-50 \mathrm{gm}) / \mathrm{plant} \\
\end{array}$ & SST $(<25$ gm $) /$ plant \\
\hline \multicolumn{4}{|l|}{$1^{\text {st }}$ factor } \\
\hline M & $7.983333^{\mathrm{a}}$ & $3.73333^{\mathrm{a}}$ & $0.43333^{b}$ \\
\hline UM & $6.45^{\mathrm{b}}$ & $2.60^{\mathrm{b}}$ & $0.60^{\mathrm{a}}$ \\
\hline F-test & $*$ & $* *$ & $*$ \\
\hline LSD & 1.37 & 0.706 & 0.124 \\
\hline $\operatorname{Sem}( \pm)$ & 0.45435 & 0.2341 & 0.04127 \\
\hline \multicolumn{4}{|l|}{$2^{\text {nd }}$ Factor } \\
\hline $10 \mathrm{~cm}$ & $7.175^{\mathrm{b}}$ & $3.35^{\mathrm{a}}$ & $0.500^{\mathrm{ab}}$ \\
\hline $15 \mathrm{~cm}$ & $9.025^{\mathrm{a}}$ & $3.75^{\mathrm{a}}$ & $0.425^{\mathrm{b}}$ \\
\hline $20 \mathrm{~cm}$ & $5.45^{\mathrm{b}}$ & $2.40^{\mathrm{b}}$ & $0.625^{\mathrm{a}}$ \\
\hline F-test & $* *$ & $*$ & $*$ \\
\hline LSD & 1.68 & 0.864 & 0.152 \\
\hline $\operatorname{Sem}( \pm)$ & 0.5564 & 0.2867 & 0.5055 \\
\hline \multicolumn{4}{|l|}{ Interaction } \\
\hline$M+10$ & 7.55 & $3.5^{\mathrm{b}}$ & 0.50 \\
\hline $\mathrm{M}+15$ & 9.7 & $5.1^{\mathrm{a}}$ & 0.25 \\
\hline $\mathrm{M}+20$ & 6.7 & $2.6^{\mathrm{b}}$ & 0.55 \\
\hline $\mathrm{UM}+10$ & 6.8 & $3.2^{\mathrm{b}}$ & 0.50 \\
\hline $\mathrm{UM}+15$ & 8.35 & $2.4^{\mathrm{b}}$ & 0.60 \\
\hline $\mathrm{UM}+20$ & 4.20 & $2.2^{\mathrm{b}}$ & 0.7 \\
\hline F-test & NS & $*$ & NS \\
\hline LSD & 2.37 & 1.22 & 0.215 \\
\hline Sem $( \pm)$ & 0.78697 & 0.405 & 0.07149 \\
\hline Grand mean & 7.22 & 3.17 & 0.517 \\
\hline CV & 21.8 & 25.6 & 27.7 \\
\hline
\end{tabular}

Note: (treatment means with the same letter do not differ significantly at $\mathrm{p}=0.05$ by DMRT. $\mathrm{CV}=$ Coefficient of variation. LSD $=$ least significant difference, $\mathrm{SEM}=$ Standard error of mean) and (LST indicates "large size tuber $>50 \mathrm{gm}$ ", MST indicates "Medium size tuber 25-50gm "and SST, indicate "Small size tuber $<25$ gm per plant" respectively):

Table 11. Correlation analysis matrix among different growth, yield and quality parameter.

\begin{tabular}{|c|c|c|c|c|c|c|c|c|c|c|c|}
\hline & PH & LFN & $\mathbf{C P}$ & ASN & TN & TW & LST & MST & SST & UNMT & MT \\
\hline PH & 1 & & & & & & & & & & \\
\hline LFN & $0.632 * * *$ & 1 & & & & & & & & & \\
\hline $\mathrm{CP}$ & $0.797 * * *$ & $0.759 * * *$ & 1 & & & & & & & & \\
\hline ASN & $0.546 * *$ & $0.621 * * *$ & $0.62 * * *$ & 1 & & & & & & & \\
\hline $\mathrm{TN}$ & 0.137 & $0.521 * *$ & $0.427 *$ & 0.1895 & 1 & & & & & & \\
\hline TW & $0.719 * * *$ & $0.501 * *$ & $0.744 * * *$ & $0.417 *$ & $0.463 *$ & 1 & & & & & \\
\hline LST & $0.504^{* *}$ & $0.554^{* *}$ & $0.604^{* *}$ & $0.411 *$ & $0.447^{*}$ & $0.3441^{*}$ & 1 & & & & \\
\hline MST & $0.568^{* *}$ & $0.535^{* *}$ & $0.61 * * *$ & $0.357^{*}$ & 0.340 & $0.5563 * *$ & 0.216 & 1 & & & \\
\hline SST & -0.326 & $-0.45 *$ & $-0.45 *$ & $-0.408^{*}$ & $-0.662 * * *$ & $-0.485 * *$ & -0.288 & $-0.6163 * * *$ & 1 & & \\
\hline UNMT & -0.156 & -0.29 & -0.40 & -0.312 & -0.240 & -0.305 & -0.482 & -0.0792 & 0.032 & 1 & \\
\hline MT & 0.093 & 0.265 & $0.39 *$ & 0.0874 & 0.294 & 0.31 & 0.3224 & 0.19521 & -0.0760 & $-0.481 * *$ & 1 \\
\hline
\end{tabular}

*correlation is significant at 0.05 level, ** correlation is significant at 0.01 level and *** correlation is significant 0.001 level, $\mathrm{PH}=\mathrm{plant}$ height, $\mathrm{CP}=\mathrm{canopy}$, $\mathrm{LFN}=$ leaf number, $\mathrm{ASN}=$ Aerial stem number, $\mathrm{TN}=$ tuber no per plant, $\mathrm{TW}=$ tuber weight per plant, $\mathrm{LST}=$ large size tuber ${ }^{-1}, \mathrm{MST}=\mathrm{Medium}$ size $^{-1} \mathrm{bber}^{-1}$, $\mathrm{SST}=$ Small Size tuber ${ }^{-1}$, UNMT $=$ unmarketable tuber $^{-1}, \mathrm{MT}=$ Marketable tuber

$\mathrm{r}$ value at $0.05=0.344$

$r$ value at $0.01=0.472$

$\mathrm{r}$ value at $0.001=0.599$

*indicate $\mathrm{r}$ value $>$ critical $\mathrm{r}$ value at $\mathrm{P}=0.05, * *$ indicate $\mathrm{r}$ value $>$ critical $\mathrm{r}$ value at $\mathrm{P}=0.01$ and $* * *$ indicate $\mathrm{r}$ value $>$ critical $\mathrm{r}$ value at $\mathrm{P}=0.001$.

The result of correlation analysis showed that tuber number per plant $(\mathrm{r}=0.463)$, aerial stem per plant $(\mathrm{r}=0.417)$ correlated significantly and positively $(\mathrm{P}<0.05)$ with total tuber weight per plant. Likewise, plant height $\left(\mathrm{r}=0.719^{* * *}\right)$, canopy $\left(\mathrm{r}=0.744^{* * *}\right)$ correlated significantly and positively $(\mathrm{P}<0.001)$ with total tuber weight per plant and leaf number per plant $\left(\mathrm{r}=0.501^{* *}\right)$ also correlated significantly and positively $(\mathrm{P}<0.01)$ with total tuber weight per plant. These result showed that any positive increase in such character had boasted total tuber yield. On the other hand negative and significant correlation were determined between small size tuber with leaf number, canopy, aerial stem per plant, tuber number per plant, tuber weight per plant etc.

Plant characters also show significant association with one another. Large size tuber per plant is also significantly and positive correlated with plant height $(\mathrm{r}=0.504 *)$, leaf number per plant $\left(\mathrm{r}=0.554^{* *}\right)$, canopy $(0.604 * *)$, aerial stem per plant $\left(\mathrm{r}=0.411^{*}\right)$, tuber weight per plant $(0.3441)$ and similarly all other parameter are also correlated among each other and with other parameter as shown in the Table 11. 


\section{Conclusion}

Finding of the result indicated that among three different planting depths, $15 \mathrm{~cm}$ depth found to be significantly superior for plant height, leaves number, canopy, aerial stem per plant, large size tuber per plant, medium size tuber per plant, tuber number $\mathrm{m}^{-2}$, tuber yield $\mathrm{m}^{-2}$ as compared to other planting depth. While more number of small size tubers per plant and more number of unmarketable tubers per plant were produced at $20 \mathrm{~cm}$ depth. Mulching significantly increased all growth, yield and quality parameter except number of small size tuber per plant and unmarketable tuber per plant that was maximum in un-mulched condition. In case of interaction between the two factors all other parameter were found insignificant except shoot dry weight and medium size tuber per plant but combination of mulch with $15 \mathrm{~cm}$ depth produced maximum growth, yield and quality parameter as compared with other combination.

The correlation coefficient between plant height, canopy, and aerial stem per plant was significantly and positively correlated with tuber weight per plant whereas negative and significant correlation were determined between small size tuber with leaf number, canopy, aerial stem per plant, tuber number per plant, tuber weight per plant.

Thus, it can be concluded from the experiment that planting potato at depth of $15 \mathrm{~cm}$ and use of mulch increased all the growth, yield and quality factor of potato.

\section{Acknowledgements}

This research was supported by the Agriculture and Forestry University, Rampur, Nepal through providing financial aid for the research. Authors are totally obliged to Mr. Prakash Ayer and T. N. Joshi helping us to complete research.

\section{References}

[1] ABPSD. (2015b). Statistical information on Nepalese agriculture.

[2] FAO STAT. (2017). FAO Statistical programme of work.

[3] AICC. (2018). Statistical information on nepalese agriculture.

[4] International Potato Center. (2013). Potato Facts and Figures.
[5] Chehaibi, S., Hamdi, W. and Abroug, K. (2013). Effects of planting depth on agronomic performance of two potato varieties grown in the Sahel region of Tunisia. Journal of Development and Agricultural Economics, 5 (7), 272-276.

[6] Sultana, N., Bari, M. S. and Rabbani, M. G. (2001). Effect of seedling tuber size and depth of planting on the growth and yield of potato. Pakistan Journal of Biological Sciences, 4 (10), 1205-1208.

[7] Pavek, M. J., \& Thornton, R. E. (2009). Planting depth influences potato plant morphology and economic value. American Journal of Potato Research, 86 (1), 56-67.

[8] Chen, S., X. Z. and D. P. (2005). Effects of corn straw mulching on soil temperature and soil evaporation of winter wheat field. Transactions of the CSAE, 21 (10), 171-173.

[9] Ahmed, N. U., Uddin, N., Afzal, M., Zaman, A. U., \& Chandra, S. (2017). Performance of mulching on the yield and quality of potato ARTICLE INFO. 4 (April 2017), 7-13.

[10] Hochmuth, G. J., R. C. H. and S. M. O. (2001). Polyethylene mulching for early vegetable production in North Florida.

[11] Rykaczewska, K. (2013). The Impact of High Temperature during Growing Season on Potato Cultivars with Different Response to Environmental Stresses. 2013 (December), 23862393.

[12] Kar, G. 2003. (2003). Tuber yield of potato as influenced by planting dates and mulches. J Agometeorology, 5, 60-67.

[13] Cadavid, L. F., M. A. EL - Sharkawy, and A. A. (1998). Long term effects of mulch, fertilization and tillage on cassava grown in sandy soils in northern Columbia. Field Crops Res., $57,45-56$.

[14] Muthoni, J., J. Kabira, H. S. and R. M. (2014). Regulation of potato tuber dormancy: Aus. J. Crop Sci., 8 (5), 754-759.

[15] Tanyaradzwa, Z. L., Tuarira, M., Moses, M., \& Jefta, T. (2015). Effects of planting depth and variety on container $\begin{array}{lllll}\text { produced } & \text { potatoes. } & 3 & \text { (1), } & 1-7 \text {. }\end{array}$ https://doi.org/10.17957/JGIASS/3.1.675.

[16] Iritani, W. M., L. D. Weller, and N. R. K. (1983). Relationships between stem number, tuber set and yield of Russet Burbank potatoes. American Potato j Ournal, 60 (6), 423-431.

[17] Jefferies, R. A., \& Mackerron, D. K. L. (1987). SHORT NOTE Thermal time as a non-destructive method of estimating tuber initiation in potatoes. 249-252. 